\title{
THE FINAL FRONTIER: THE LAWS OF ARMED CONFLICT AND SPACE WARFARE
}

\section{Jackson Maogoto* and Steven Freeland**} [I]f there was ever a threat to our national security [in space], the best - the only - way to solve the problem is to
take weapons into space ${ }^{1}$

During history every medium - air, land and sea — has seen conflict. Contemporary reality indicates that space will be no different. The notion of space warfare is becoming 'a virtual certainty'

[T] he lawful bearing of arms-under a strict code of military justice and within a corpus of humanitarian law — has been accepted as a practical necessity ${ }^{3}$

[The humanitarian law of armed conflict] applies to all forms of warfare and to all kinds of weapons, those of the past, those of the present and those of the future ${ }^{4}$

\section{INTRODUCTION}

On 14 December 2001, in an effort to consolidate its policy of 'space control', United States President George Bush announced the withdrawal of the United States from the Treaty on the Limitation of Anti-Ballistic Missile Systems (ABM Treaty), ${ }^{5}$ invoking Article 15 of that

\footnotetext{
${ }^{*}$ LL.B (Hons) (Moi), LL.M (Hons) (Cantab), PhD (Melb), GCertPPT (UoN), Senior Lecturer in International Law, University of Newcastle (Australia).

*** Associate Professor in International Law, University of Western Sydney (Australia); Visiting Professor of International Law, University of Copenhagen, (Denmark); Member of the Space Law Committee of the International Law Association; Member of the International Institute of Space Law.

${ }^{1}$ William Scott, USSC Prepares for Future Combat Mission in Space, 145 AVIATION WK. \& SPACE TeCh. 51, 55 (1996).

2 Comm'n to ASSESS U. S. NAT'L SECURITY SPACE MgMT. \& ORg. (2001), http://www.dod.mil/pubs/space20010111.pdf (last accessed Oct. 13, 2007).

${ }^{3}$ JOHN KEEGAN, A HISTORY OF WARFARE 5 (1993).

${ }^{4}$ Legality of the Threat or Use of Nuclear Weapons, Advisory Opinion, 1996 I.C.J. 259 (July 8). In this important opinion, the Court cites several of the numerous statements advanced by States for the conclusion that the law of armed conflict applies to nuclear weapons whether nuclear weapons were in existence at the time the law developed or not. Two relevant points arise from this discussion. First, as the Court quotes from the representative statements of States, the following phrases are used and are assumed by the court to be synonymous: 'international humanitarian law' (New Zealand), 'rules applicable to armed conflict' (Russian Federation), 'jus in bello' (United Kingdom), and 'law of armed conflict' (United States). Second, as the noted quotation above makes clear, the court's conclusion that humanitarian law applies to nuclear weapons is equally applicable to any 'past ... present and ... future' forms of warfare and kinds of weapons. This statement certainly provides the International Court of Justice's answer to the question of whether the law of war will apply to space warfare.

${ }^{5}$ See Colin Powell, Sec'y of State, Statement on the Achievement of the Final Reductions under the START Treaty (Dec. 5, 2001) (on file with the U.S. Department of State), available at http://www.state.gov/secretary/former/powell/remarks/2001/dec/6674.htm.
} 
instrument. ${ }^{6}$ The key reason given by President Bush for the decision to withdraw from the treaty was because it was outdated and a relic of the Cold War. ${ }^{7}$ However, there was a more practical purpose, since the ABM Treaty expressly prohibited the development, testing and deployment of sea-based, air-based, space-based, and mobile land-based ABM systems. ${ }^{8}$ As a result, withdrawal from the ABM Treaty removed conventional restrictions on the United States to develop what would otherwise have been expressly prohibited weapon systems and, in particular, space-based devices that it perceives to form an integral part of its policy of ensuring that it retains its military dominance.

The genesis of the 2001 decision by the Bush Administration can be traced back to the First Persian Gulf War. During that conflict, the Patriot batteries deployed by Israel helped make a case for the role of Theatre Missile Defence (TMD). ${ }^{9}$ In light of this, pressure began building in the United States to either loosen or completely divest its anti-ballistic missile technology from the constraints of the ABM Treaty. On 5 December 1991, shortly after the conclusion of the Gulf War, the United States Congress passed the Missile Defence Act of $1991 .^{10}$ This legislative enactment put Congress on record as officially supporting a National Missile Defence program. It stated in part:

\footnotetext{
${ }^{6}$ Anti-Ballistic Missile Systems Treaty, U.S.-U.S.S.R., May 26, 1972, 23 U.S.T. 3435, art. XV [hereinafter ABM Treaty] (stating "1. This Treaty shall be of unlimited duration. 2. Each Party shall, in exercising its national sovereignty, have the right to withdraw from this Treaty if it decides that extraordinary events related to the subject matter of this Treaty have jeopardized its supreme interests. It shall give notice of its decision to the other Party six months prior to withdrawal from the Treaty. Such notice shall include a statement of the extraordinary events the notifying Party regards as having jeopardized its supreme interests.")

${ }^{7}$ See John Diamond, Missile Pact on Brink: U.S. Says Imminent Testing May Violate ABM Treaty, CHI. TRIB., July 13, 2001, at 1 .

${ }^{8}$ ABM Treaty, supra note 6, at art. V.

${ }^{9}$ The proposed United States TMD systems will employ interceptor missiles without warheads, relying on kinetic energy to kill their targets. The lower tier system will ram its target after the target re-enters the earth's atmosphere on its downward trajectory; the upper tier system rams its target during the target's mid-course trajectory intercepting their targets in outer space. See Ballistic Missile Defense Organization, Fact Sheet 97-05: Ballistic Missile Defense-The Core Programs (1997) 1-2. See Ballistic Missile Defense Organization, Fact Sheet 97-19: Navy Theatre Wide Ballistic Missile Defense Program (1997) 2.

${ }^{10}$ Missile Defense Act of 1991, (105 Stat 1290) §§ 231-40 (1991).
} 
It is a goal of the United States to deploy an anti-ballistic missile system, including one or an adequate additional number of anti-ballistic missile sites and space-based sensors, that is capable of providing a highly effective defense of the United States against limited attacks of ballistic missiles. ${ }^{11}$

Four years later, in 1995, a bill was introduced in Congress entitled the Defend America Act. ${ }^{12}$ Section 4 of that instrument provided that, within one year of its enactment, there should be at least one test of either an $\mathrm{ABM}$ interceptor based in space; a sensor in space capable of providing data directly to an ABM interceptor; or an existing air defence, theatre missile defence, or early warning system, so as to demonstrate the country's capability to counter strategic ballistic missiles or their elements in flight trajectory. ${ }^{13}$ In the same year, an almost identical provision was inserted into the Ballistic Missile Defense Act. ${ }^{14}$ The legislation sought to allow deployment of multiple ground-based ABM sites to provide effective defence of the United States against limited ballistic missile attack; unrestricted use of sensors based within the atmosphere and in space; and increased flexibility for development, testing, and deployment of follow-on national missile defence systems. With the introduction of these initiatives, the future of the ABM Treaty was doomed, since it purported to restrain these emerging military and technological goals.

Since the 2001 decision to withdraw from the ABM Treaty, the United States has been actively pursuing innovative military technology that it considers as essential to its decision to not only establish a national missile shield system, but to also locate important elements of the same in strategic locations overseas. This strategy has lead to a chorus of protests, particularly from the United States' principal military competitors, Russia and China. These protests have reached a heightened crescendo, specifically from the former, as a consequence of the decision by the United States in 2006 to locate parts of the system in the former communist

\footnotetext{
${ }^{11} I d$. at $§ 232$ (a) (1).

${ }^{12}$ Defend America Act of 1995, H.R. 2483, 104th Cong. § 1 (1995).

${ }_{14}^{13} I d$. at $\S 4$.

${ }^{14}$ National Defense Authorization Act For Fiscal Year 1996, H.R. REP. No. 104-406 to accompany H.R. 1530, 104th Cong. $\$ 235$ (1995), available at http://www.fas.org/spp/starwars/congress/1995_r/h104406.htm.
} 
bloc countries of Poland and the Czech Republic, following detailed bilateral talks with those two countries.

The proposed United States ballistic missile defence shield system would involve the deployment of space-based sensors, including a space and missile tracking system and other space-based sensors which could provide cueing to the ground-based interceptors. ${ }^{15}$ The decision to locate interceptor missiles in Poland and associated radar systems and infrastructure in the Czech Republic ${ }^{16}$ incensed Russia, leading to a stream of caustic and even inflammatory public comments. Seemingly fearful that the system may eventually lead to neutralization of its own strategic missiles, Russia has indicated that it may consider freezing its commitments to several arms reduction treaties, including the 1988 Intermediate Range Nuclear Forces Treaty (INF Treaty) and the 1990 Conventional Forces in Europe Treaty (CFE Treaty), setting the stage for a potential arms race.

At the same time, China has been rapidly consolidating its status as a space power, racheting up the stakes very significantly with the test of an anti-satellite weapon. In January 2007, the Chinese military launched a KT-1 rocket that successfully destroyed a redundant Chinese Feng Yun 1-C weather satellite, which it had launched in 1999, in Low Earth Orbit approximately 800 kilometres above the earth. This generated a great deal of alarm and unease in Washington and elsewhere, particularly as it indicated quite starkly the increasing technological capabilities of the Chinese military. ${ }^{17}$ With China predicted to become the ascendant 'superpower' in the twenty-first century, this space-technology rivalry (particularly

\footnotetext{
${ }^{15} I d$.

${ }_{16}$ See, e.g., Paul Reynolds, Echoes of Cold War in Missile Arguments, BBC NEWs, Apr. 26, 2007, http://news.bbc.co.uk/2/hi/europe/6583587.stm; Thom Shanker, Pentagon Invites Kremlin to Link Missile Systems, N.Y. TIMES, Apr. 21, 2007, at A1.

${ }^{17}$ See, e.g., Michael R. Gordon \& David S. Cloud, U.S. Knew of China's Missile Test, but Kept Silent, N.Y. TimeS, Apr. 23, 2007, at A1; Peter Spiegel, U.S. Gauges the Threat to Satellites, THE Los ANGELES Times, Apr. 22,2007 , at A1.
} 
its military utility) among the space powers appears to be intensifying. It is to be remembered that in 2000, China unveiled an ambitious ten-year space program. ${ }^{18}$

While one of the strongest immediate motivations for this program appears to be political prestige, China's space efforts almost certainly will contribute to the development of improved military space systems. ${ }^{19}$ With the United States actively pursuing a national missile defense program, in 2003 a Chinese military official commented that China's army had already introduced the concept of space force strength, ${ }^{20}$ in apparent reference to a similar United States military concept. ${ }^{21}$ An indication that Chinese space programs are significantly driven by military and security considerations is the fact that the Chinese space program has always been under the command of senior officers of the People's Liberation Army. ${ }^{22}$

Each of these developments indicates a rapidly expanding perception among the major powers of the need for space-based systems in support of military operations. This perception

18 Mark Wade, China's Space Activities, EnCYCloPAEDIA Astronautica (2000), http://www.astronautix.com/articles/chiities.htm.

${ }^{19}$ Leonard David, Pentagon Report: China's Space Warfare Tactics Aimed at U.S. Supremacy, SPACE, Aug. 1, 2003, http://www.space.com/news/china_dod_030801.html.

${ }^{20} I d$.

${ }^{21}$ In 1998, the United States Space Command (USSPACECOM) published its Long Range Plan outlining the United States military vision for control of space and developing a capacity to project force from space. The first two mission statements of USSpacecom's Vision For 2020 are pointed: "space support" and "force enhancement" meaning the use of space assets to facilitate military operations of combat forces on land, sea, and air. The next two mission statements: "space control" and "force application" are more controversial as they suggest the weaponization of space, and are most closely related to combat in a future theatre of military space operations. Overall these four mission areas encapsulate 'space control'. U. S. SPACE COMMAND, LONG RANGE PLAN, USSpacecom Vision For 2020 (1998). Even more significant was another document issued in 1999 by United States Department of Defence ('DoD'), which expanded upon, and reinforced themes raised by USSpacecom's Vision For 2020 Among other space issues, the DoD policy states: "Purposeful interference with US space systems will be viewed as an infringement on our sovereign rights. The US may take all appropriate self-defense measures, including, if directed by the National Command Authorities ('NCA'), the use of force, to respond to such an infringement on US rights”. DEP'T OF DEF., Directive Number $3100.10 \S 4.2 .1$ (1999).

${ }^{22}$ Kremlin Voices Concern at U.S. Conventional Missile Plans, Defense News, May 11, 2006, http://www.defensenews.com/story.php? $\mathrm{F}=1767408 \& \mathrm{C}=$ airwar. Initially the Chinese space program was organized under the Army, particularly the Second Artillery Corps. See Gabriele Garibaldi, The Chinese Threat to American Leadership, http://taiwansecurity.org/IS/2004/IS-Garibaldi-0704.htm (last accessed Oct. 30, 2007). See China's Spacecraft, SPACE TODAY, http://www.spacetoday.org/China/ChinaSatellites.html (noting that among another achievements, in January 2000, China launched its first military communications satellite as part of a People's Liberation Army command-and-control network linking forces for combat). 
is being translated into reality by the very significant resources now devoted by each of them to the development of ever-more effective (and potent) space-related weaponry. Without wishing to appear melodramatic, the prospect of a celestial war can no longer be regarded as mere fantasy. Just as States have already been undertaking what might be termed 'passive' military activities in outer space since the advent of space technology, outer space is increasingly being used as part of active engagement in the conduct of armed conflict. ${ }^{23}$ Not only is information gathered from outer space - through, for example, the use of remote satellite technology and communications satellites - used to plan military engagement on earth, space assets are now used to direct military activity and represent an integral part of the military hardware of the major powers. It is now within the realms of reality to imagine outer space as an emerging theatre of warfare.

Space warfare is the focus of serious planning as the militaries of major powers brace for new forms of high-tech combat in the twenty-first century. ${ }^{24}$ For example, the United States Air Force (USAF) is increasingly focusing on space - " not just on how to operate there, but how to protect operations and attack others in space." ${ }^{25}$ USAF has established a "space operations directorate" at Air Force headquarters, and has started a new Space Warfare School and activated two new units: the $76^{\text {th }}$ Space Control Squadron (tasked with fighting in space) and the $527^{\text {th }}$ Space Aggressor Squadron (whose mission is to probe the United States military for new vulnerabilities). ${ }^{26}$

\footnotetext{
${ }^{23}$ See Thomas Ricks, Space Is Playing Field for Newest War Game; Air Force Exercise Shows Shift in Focus, WASH.. POST., Jan. 29, 2001, at A1.

${ }^{24} I d$.

${ }^{25}$ See id.

${ }^{26}$ See id.
} 
As mentioned above, it is not just the United States and Russia (the successor of the Soviet Union) that are currently seeing space warfare as a distinct possibility in the future. ${ }^{27}$ The first Gulf War also convinced China's military leadership of the importance of high-tech integrated warfare platforms, and the ability of sophisticated space-based command, control, communications, and intelligence systems to link land, sea and air forces. ${ }^{28}$ With the United States' abrogation of its ABM Treaty commitments and the implications of its ballistic missile defence system, Russia and China are accelerating development of space weaponry to counteract the envisaged capabilities of America's Ballistic Missile Defence program. ${ }^{29}$ The straight-line prediction would be that over the next decade or so, we should expect a discernible effort to achieve a 'strike-back assured' destruction posture, which would ensure that Russia and China remain America's peer military competitors.

In addition, the advent of China as a major space power - symbolized not only by that country, in 2003 , becoming the third country to successfully send a man into space, ${ }^{30}$ but also by its ambitious plans for missions both to the $\mathrm{Moon}^{31}$ and $\mathrm{Mars}^{32}$ - has given rise to further concerns about the use of outer space for strategic purposes not necessarily in keeping with the underlying co-operative principles of the international law of outer space. Outer space has

\footnotetext{
${ }^{27}$ See supra note 17.

${ }^{28}$ The authors aver that the basis of this assertion is borne out by the tenor of the following sources: See Wang Xiaodong, Special Means of Warfare in the Information Age: Strategic Information Warfare, Jianchuan Zhishi [Warship Information], June, 30, 1999, in FBIS-FTS19990727000426 and FBIS-FTS19990727000941; Wang Baocun, Subduing Enemy Force Without Battle and Informationized Warfare, Zhongguo Junshi Kexue [China Military Science], May 4, 1999, 60-63 in FBIS-FTS19990823000602; James Perry, Operation Allied Force: The View from Beijing 14(2) AEROSPACE POWER J. 79, 81-2 ( Summer 2000); Timothy L. Thomas, Like Adding Wings to the Tiger: Chinese Information War Theory and Practice, http://leavwww.army.mil/fmso/documents/chinaiw.htm (last visited Oct. 3, 2007).

${ }^{29}$ See supra note 17.

${ }^{30}$ Britannica Online Encyclopedia. History of Space Exploration, http://www.britannica.com/eb/article-237045 (last visited Oct. 30, 2007).

${ }^{31}$ See Mark Carreau, Only time will tell for the U.S.-China space Union, KNIGHT RIDDER TRIB. Bus. News, May 7, 2006, at 1.

32 See Jim Yardley \& William J. Broad, Heading for the Stars, And Wondering if China Might Reach Them First; THE NEXT SPACE RACE, N.Y. TIMES, Jan. 22, 2004, at A8.
} 
in recent times been referred to as the "Fourth Territory" (alongside land, sea and airspace) ${ }^{33}$ - a notion that clearly flies in the face of both the "common heritage of mankind" and "nonappropriation" principles that form the bedrock of the international law of outer space. ${ }^{34}$

With these developments in mind, this article focuses on the application of the current laws of war to the emerging phenomenon of space weaponization and the increasing likelihood in the next few decades of space becoming a battleground. This predicament requires new ways of thinking and legal regulation, considering that the existing principles of the Laws of Armed Conflict (LOAC) are primarily focused on air, land and terrestrial warfare. ${ }^{35}$ This article addresses the special problems arising from applying the LOAC to space warfare. It will also analyze the significant problems posed by space assets dedicated to uses of both a civilian and military nature - the concept of the "dual-use satellite" - as well as legal problems raised by the possible military activities of astronaut combatants, in light of the particular status conferred on all astronauts under current international space law principles.

\section{CUSTOMARY AND CONVENTIONAL PRINCIPLES OF THE LAWS OF WAR}

Given the misery and destruction wrought by warfare through the centuries, warring nations have developed customary practices seeking to ameliorate its devastating effects. ${ }^{36}$ These principles of international humanitarian law -jus in bello - have emerged over time, as the international community has gradually agreed that there should be certain legal constraints

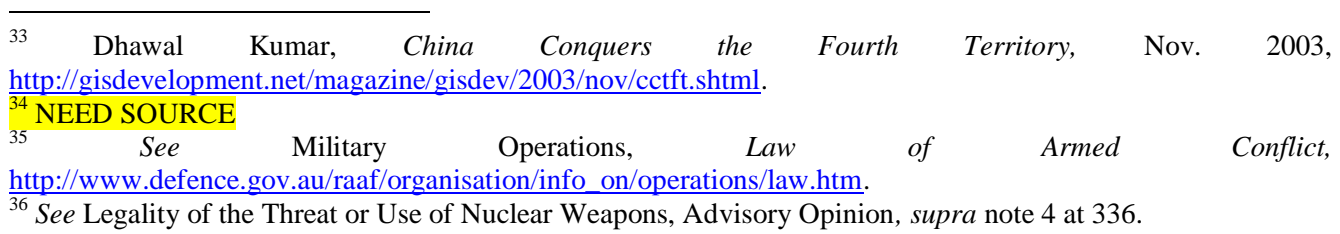


applicable to the conduct of armed conflict. ${ }^{37}$ Wars have been with us since time immemorial and it has only been relatively recently that minimum international standards have been developed to regulate how, with what and against whom they could be fought - in effect the rules that have developed are "intended to limit the terrible effects of war." ${ }^{38}$ Even though "war" as a concept was declared illegal by The Kellog-Briand Pact, ${ }^{39}$ - which still remains in force to this day - it is evident that armed conflict still continues and has become more complex, particularly given the increasing role of non-State actors. Moreover, the scope for cataclysmic destruction and loss of life has also increased due to the development of sophisticated weaponry, which includes the use of space technology. ${ }^{40}$

The 'laws and customs of war' had its origins in the customary practices of armies on the battlefield and has developed as an important branch of international law. ${ }^{41}$ The application of these customary practices was not uniform, ${ }^{42}$ and it therefore became evident that more formalized standards were required. A major step forward in the development of the rules of war, which inter alia limit the method and means of conducting warfare and also provide for classes of protected persons and protected objects, came with the Brussels Conference of 1874 and, more significantly, The Hague Peace Conferences of 1899 and 1907, which gave rise to some important standard-setting treaties that are still applicable today. ${ }^{43}$ The 1899

\footnotetext{
${ }^{37} I d$.

${ }^{38} I d$. at 558.

${ }^{39}$ Art. I of the Treaty Providing for the Renunciation of War As An Instrument of National Policy provides: "The high contracting parties solemnly declare in the names of their respective peoples that they condemn recourse to war for the solution of international controversies, and renounce it as an instrument of national policy in their relations with one another." Treaty Providing for Renunciation of War as an Instrument of National Policy [The Kellogg-Briand Pact] art. I, Aug. 27, 1928, 94 L.N.T.S. 57.

${ }^{40}$ See infra Part IV-V.

41 See generally the sentiments and analysis OF JeAn MARIE HeCKAERTS ET. AL., CUSTOMARY INTERNATIONAL Humanitarian LaW (Cambridge University Press 2005); See Jackson MaOgoto, State Sovereignty \& INTERNATIONAL CRIMINAL LAW: VerSAILleS TO ROME 311(Transnational Publishers 2003). Intro., Chap. 1; See JACKSON MAOGOTO, WAR CRIMES \& REALPOLITIK: INTERNATIONAL JUSTICE FROM WORLD WAR I TO THE $21^{\text {ST }}$ CENTURY 267 (Lynne Rienner Publishers 2004).

${ }^{42}$ See generally HECKAERTS ET. AL. supra note 41.

43 The 1899 Hague Conventions were: Convention (I) for the Pacific Settlement of International Disputes, Convention (II) with Respect to the Laws and Customs of War on Land, Convention (III) Relative to the
} 
Conference concluded that " $[t]$ he right of belligerents to adopt means of injuring the enemy is not unlimited." ${ }^{, 44}$

Further treaties followed, specifying in greater detail the limits of what constituted acceptable behaviour in the context of armed conflict. As an example, those provisions of the Hague Conventions that applied the laws of war to restrict the use of poison or poisoned weapons and asphyxiating gases were further extended by the 1925 Geneva Protocol. ${ }^{45}$ However, the horrors of the Second World War demonstrated the inadequacy of the existing rules, particularly in relation to the treatment of civilians and non-combatants. The four 1949 Geneva Conventions were concluded to address these issues. ${ }^{46}$ These were strengthened by the Additional Protocols of $1977 .{ }^{47}$

Opening of Hostilities, Convention (IV) Respecting the Laws and Customs of War on Land, Convention (V) Respecting the Rights and Duties of Neutral Powers and Persons in Case of War on Land, Convention (VI) Relating to the Status of Enemy Merchant Ships at the Outbreak of Hostilities, Convention (VII) Relating to the Conversion of Merchant Ships into War-Ships, Convention (VIII) Relative to the Laying of Automatic Submarine Contact Mines, Convention (IX) Concerning Bombardment by Naval Forces in Time of War, Convention (X) for the Adaption to Maritime War of the Principles of the Geneva Convention, Convention (XI) Relative to Certain Restrictions with Regard to the Exercise of the Right of Capture in Naval War and Convention (XIII) Concerning the Rights and Duties of Neutral Powers in Naval War. Full texts can be accessed electronically at: The Avalon Project at Yale Law School :The Laws of War available at http://www.yale.edu/lawweb/avalon/lawofwar/lawwar.htm_and THE LAWS OF ARMED CONFLICTS: A Collection of Conventions, Resolutions, \& Other Documents (D Schindler, J Toman eds.) (3d ed., 2000).

${ }^{44}$ Hague Convention Respecting the Laws and Customs of War on Land and its Annex: Regulations Concerning the Laws and Customs of War on Land art. 22, Oct. 18, 1907, 1 Bevans 631.

${ }^{45}$ Protocol For The Prohibition Of The Use In War Of Asphyxiating, Poisonous Or Other Gases, And Of Bacteriological Methods Of Warfare, appendix XXII, June 17, 1925, 94 LNTS 65.

${ }^{46}$ Geneva Convention for the Amelioration of the Condition of the Wounded and Sick in Armed Forces in the Field, Oct. 21, 1950 [hereinafter Geneva Convention I], 75 UNTS. 31; Geneva Convention for the Amelioration of the Condition of the Wounded, Sick and Shipwrecked Members of Armed Forces at Sea, Oct. 21, 1950 [hereinafter Geneva Convention III], 75 UNTS. 85; Geneva Convention Relative to the Treatment of Prisoners of War, Oct. 21, 1950 [herenafter Geneva Convention III], 75 UNTS. 135;Geneva Convention Relative to the Protection of Civilian Persons in Time of War, Oct. 21, 1950, [ hereinafter Geneva Convention IV], 75 UNTS. 287.

${ }^{47}$ Protocol Additional to the Geneva Conventions of 12 August 1949, and Relating to the Protection of Victims of International Armed Conflicts (Protocol I), June 8, 1977, 1125 U.N.T.S. 3 [hereinafter Additional Protocol I]; Protocol Additional to the Geneva Conventions of 12 August 1949 and Relating to the Protection of Victims of Non-International Armed Conflicts (Protocol II), June 8, 1977, 1125 U.N.T.S. 609 [hereinafter Additional Protocol II] adopted on 8 June 1977 by the Diplomatic Conference on the Reaffirmation and Development of International Humanitarian Law applicable in Armed Conflicts. 
International humanitarian law is now a well-developed area of international law, covering many aspects of terrestrial warfare. The importance of the obligations arising under international humanitarian law, particularly those contained in The Hague Conventions of 1899 and 1907 and the Geneva Conventions of 1949 and their Additional Protocols of 1977, has recently been reaffirmed by the United Nations Security Council in a landmark resolution relating to the protection of civilians in armed conflict. ${ }^{48}$ In addition, the establishment of various national, regional and international mechanisms of justice to enforce these fundamental principles - culminating in the International Criminal Court, the world's first permanent court of its kind - clearly indicates that the international community has determined that those senior officials (both military and political) who breach these norms are to be brought to account. ${ }^{49}$

As the customs of war have evolved into the customs and laws of war, the dominant objective underlying the law as it relates to military force has remained constant and can be summed up in one word: restraint. ${ }^{50}$ The seminal statement in this regard is encapsulated in Article 22 of

\footnotetext{
${ }^{48}$ S.C. Res. 1674, II 6, U.N. Doc. S/RES/1674 (April 28, 2006).

${ }^{49}$ See, Steven Freeland, How Open Should the Door Be?-Declarations by non-States Parties under Article 12(3) of the Rome Statute of the International Criminal Court, 75 NORDIC J. OF INT'L L. 211-41 (2006) (describing the powers and operation of the International Criminal Court).

50 "To exist as a principle of law, military necessity must have independent legal valence. That can, by definition, only occur when it is characterized as a limitation, for, as a general rule, all that is not prohibited in international law is permitted." Michael N. Schmitt, Book Review: Law on the Battlefield, 8 U.S. A.F. ACAD. J. L. STUD. 255, 257 (1997-1998) (reviewing A.P.V. ROGERS, LAW ON THE BATTLEFIELD (1996)). This analysis applies to all principles and tenets of the law of war-thus all are restrictions on behavior. As for the general proposition in international law that all that is not forbidden is permitted, the International Court of Justice recently quoted from two previous cases, as it recounted the position of several States leading up to its advisory opinion on the threat or use of nuclear weapons. See Legality of the Threat or Use of Nuclear Weapons, Advisory Opinion, supra note 4, at 238-39 (July 8) (referencing the Lotus and Nicaragua cases). In the Lotus case, the Permanent Court of International Justice (PCIJ) stated that 'restrictions upon the independence of States cannot ... be presumed' and that international law leaves to States 'a wide measure of discretion which is only limited in certain cases by prohibitive rules.' See also, PCIJ (ser. A) No. 10, at 18-19. More recently, the International Court of Justice stated that "in international law there are no rules, other than such rules as may be accepted by the State concerned, by treaty or otherwise, whereby the level of armaments of a sovereign state can be limited." See also, Military and Paramilitary Activities (Nicaragua. v. United States) 1986 I.C.J. 4, 135. Though the latter language specifically addressed armaments, it rests on the rationale from the Lotus case-unless prohibited, an action is allowed.
} 
the Second Convention adopted by the 1899 Hague Peace Conference, which provides: 'The right of belligerents to adopt means of injuring the enemy is not unlimited. ${ }^{, 51}$

There are no treaties establishing specific jus in bello principles for space combat; those customary and conventional principles provide the most authoritative source for application to activities in outer space. A significant observation regarding the application of the laws of war to military space operations relates to what became known at the Hague diplomatic conferences as the "Martens Clause." $" 52$ This clause so named for the Russian delegate who articulated and proposed its inclusion, was inserted into the preamble of the 1899 Second Convention and the 1907 Fourth Convention. ${ }^{53}$ The clause was intended to supplement the prohibitory rules adopted at both conferences. The clause appears (in slightly differing versions) in several laws of war documents, and generally provides as follows:

Until a more complete code of the laws of war has been issued, the high contracting parties deem it expedient to declare that, in cases not included in the Regulations adopted by them, the inhabitants and the belligerents remain under the protection and the rule of the principles of the law of nations, as they result from the usages established among civilized peoples, from the laws of humanity, and the dictates of the public conscience. ${ }^{54}$

Versions of the principle have appeared in each of the four 1949 Geneva Conventions, ${ }^{55}$ the Additional Protocol I, ${ }^{56}$ and the 1980 Convention on Conventional Weapons. ${ }^{57}$ This widespread incorporation of the principle, adopted by the vast majority of States, strongly

\footnotetext{
${ }^{51}$ Hague Convention II, supra note 43, at art. XXII.

52 Rupert Tucehurst, The Martens Clause and the Laws of Armed Conflict, Nov. 1997, http://www.icrc.org/Web/Eng/siteeng0.nsf/html/57JNHY (last visited Oct. 30, 2007).

${ }^{54}$ Hague Convention IV preamble, supra note 43.

${ }^{55}$ Geneva Convention I, supra note 46, at art. 63 If 4; Geneva Convention II, supra note 46, at art. 62 9f 4; Geneva Convention III, supra note 46, at art. 142 II 4; Geneva Convention IV, supra note 46, at art. 158 II 4.

${ }^{56}$ Additional Protocol I, supra note 47, at art. 1(2).

${ }^{57}$ Convention on Prohibitions or Restrictions on the Use of Certain Conventional Weapons which May be Deemed to be excessively injurious or to have indiscriminate effects (with protocols), Oct. 10, 1980, 1342 U.N.T.S. 7, 163[hereinafter Conventional Weapons Treaty].
} 
suggests that the Martens' Clause itself may have become a principle of customary international law. ${ }^{58}$ In the Legality of the Threat or Use of Nuclear Weapons Advisory Opinion, the International Court of Justice considered that the Martens clause principles, although deriving from 'humanity and the dictates of public conscience', affirmed that the jus in bello prohibited "harm greater than that unavoidable to achieve legitimate military objectives. ${ }^{.59}$

The continuing vitality of the doctrine expressed in the Martens' Clause will be particularly important for space warfare, increasingly thought to be the most technologically innovative form of warfare. Because the doctrine is phrased "dynamically," need to regulate means and methods of warfare developed through technological advances, it will always operate to limit the lawful prosecution of space warfare. No matter what new means or methods are developed, they will remain subject to 'the principles of international law derived from established custom, from the principles of humanity and from the dictates of public conscience. ${ }^{61}$

Subsequent to the diplomatic conference which adopted the Additional Protocols to the Geneva Conventions, there have also been a growing number of other important treaties that have added to the corpus of international humanitarian law and the rules regulating armed conflict, particularly in relation to restrictions on specific weapons and means of warfare.

\footnotetext{
${ }^{58}$ This possibility is strengthened by the claim of the International Military Tribunal at Nuremburg in 1946 that the Hague Convention IV is declaratory of customary international law. DOCUMENTS ON THE LAWS OF WAR, 44 (Adam Roberts \& Richard Guelff, eds., Clarendon Press 1989).

${ }^{59}$ See Legality of the Threat or Use of Nuclear Weapons, supra note 4, at 257.

${ }^{60}$ See Max Planck Institute For Comparative Public LaW AND InT'L LaW, ENCyClopedia of Public INTERNATIONAL LAW 252 (Rudolph Bernhardt, ed., North-Holland Publishing Co., 1982).

${ }^{61}$ Diplomatic Conference on Reaffirmation and Development of International Humanitarian Law Applicable in Armed Conflict: Protocols I and II to the Geneva Conventions art. 1(2), June 8, 1977, 16 I.L.M. 1396-97.
} 
These include, in chronological order, treaties on biological weapons, ${ }^{62}$ environmental modification, ${ }^{63}$ conventional weapons, ${ }^{64}$ chemical weapons, ${ }^{65}$ blinding lasers, ${ }^{66}$ and antipersonnel mines. ${ }^{67}$ Of these, the most likely to affect potential means and methods of space warfare is the Environmental Modification Treaty (ENMOD), which was the first instrument that dealt with deliberate destruction of the environment during warfare, although it also applies in time of peace. ${ }^{68}$ This treaty proscribes the 'military or any other hostile use of environmental modification techniques having widespread, long-lasting or severe effects as the means of destruction, damage or injury to any other State Party. ${ }^{69}$ The treaty is of particular importance to space warfare in that 'environmental modification techniques' are defined to include 'any technique for changing - through the deliberate manipulation of natural processes - the dynamics, composition or structure of the earth, including its biota, lithosphere, hydrosphere and atmosphere, or of outer space. ${ }^{70}$

ENMOD's provisions make clear that its purpose is not so much environmental protection, as a restriction against States making or attempting changes to environmental processes as an instrument of warfare. The means of warfare prohibited by the treaty need not adversely affect

\footnotetext{
${ }^{62}$ Convention on the Prohibition of the Development, Production and Stockpiling of Bacteriological (Biological) and Toxin Weapons and on Their Destruction, Apr. 10, 1972, 26 U.S.T. 583 (entered into force 26 March 1975) [hereinafter Biological Weapons Treaty].

${ }^{63}$ Convention on the Prohibition of Military or Any Other Hostile Use of Environmental Modification Techniques, May 18, 1977, 31 U.S.T. 333 (entered into force Oct. 5, 1978) [hereinafter Environmental Modification Treaty].

${ }^{64}$ Convention on Prohibitions or Restrictions on the Use of Certain Conventional Weapons which May be Deemed to be Excessively Injurious or to Have Indiscriminate Effects (with protocols), Oct. 10, 1980, No. 22495, 1342 U.N.T.S. 7 (entered into force Dec. 2, 1983)[hereinafter Conventional Weapons Treaty]. The treaty contained protocols on (1) fragments not detectable by X-rays; (2) mines, booby traps, and other devices; and (3) incendiary weapons. All three protocols went into force with the treaty in 1983. A fourth Protocol on Blinding Laser Weapons went into force on July 30, 1998. See Protocol [to the Convention on Conventional Weapons] on Blinding Laser Weapons (Protocol IV), Oct. 13, 1995, 35 I.L.M. 1218 (1996). (entered into force July 30, 1998)[hereinafter Blinding Laser Weapons Protocol].

${ }^{65}$ See Biological Weapons Treaty, supra note 62.

${ }^{66}$ See Blinding Laser Weapons Protocol, supra note 64.

${ }^{67}$ Convention on the Prohibition of the Use, Stockpiling, Production and Transfer of Anti-Personnel Mines and on their Destruction, Sept. 18, 1997, 36 I.L.M. 1507 (1997) (entered into force Mar. 1, 1999).

${ }^{68}$ See Convention on the Prohibition of Military or Any Other Hostile Use of Environmental Modification Techniques, supra note 63.

${ }^{69}$ Environmental Modification Treaty, supra note 63, art. III(1), art. I(1).

${ }^{70}$ Id. at art. III(1); art. II (emphasis added).
} 
the environment itself, because the prohibitions of Article I apply only to the use of the environment as a weapon. ${ }^{71}$ So long as space weapons do not change the outer space environment through the deliberate manipulation of natural processes, the treaty is not likely to serve as a bar to the development or use of space weapons. ${ }^{72}$

In dealing with the issue of environmental protection during times of armed conflict, the International Court of Justice has stated that it does not consider that the treaties protecting the environment could have intended to deprive a State of the exercise of its right of self-defense under international law because of its obligations to protect the environment. ${ }^{73}$ Nonetheless, the International Court of Justice did emphasize the importance of environmental considerations in the planning and conduct of military activities, stating:

States must take environmental considerations into account when assessing what is necessary and proportionate in the pursuit of legitimate military objectives. Respect for the environment is one of the elements that go to assessing whether an action is in conformity with the principles of necessity and proportionality. ${ }^{74}$

In addition to, and complementing the various treaty provisions that prescribe important rules of the jus in bello, there have emerged various fundamental principles that underpin the conduct of belligerents during warfare, thus forming a crucial part of the LOAC. ${ }^{75}$ These are the principle of military necessity, the principle of distinction and the principle of proportionality. ${ }^{76}$

\section{Military Necessity}

\footnotetext{
${ }^{71}$ Michael N. Schmitt, Green War: An Assessment of the Environmental Law of International Armed Conflict, 22 YALE J. INT'L L. 1, 82 (1997).

${ }_{73} I d$. at 84 . (noting the narrow scope of the Treaty, it "affects only a very narrow band of possible operations").

${ }_{74}^{73}$ See Legality of the Threat or Use of Nuclear Weapons, supra note 4, II 30.

${ }^{74}$ See id.

${ }^{75}$ See H. McCoubrey, The Nature of the Modern Doctrine of Military Necessity, 30 RevUe DE DroIT MiLITAIRE ET DE DROIT DE LA GuERRE 215 (1991).

76 See William Fenrick, Protecting Civilians in 21 St Century Warfare: Target Selection,

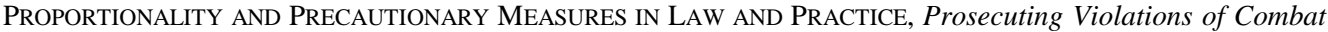
Limitations, 77, 82-83 (Mireille Hector \& Martine Jellema eds., Willem-Jan van der Wolf 2001).
} 
Military necessity ${ }^{77}$ is a fundamental principle of the LOAC circumscribing the use of force, ${ }^{78}$ by establishing a reasonable connection between destruction and the overcoming of an enemy force. Military necessity is the obligation for a belligerent to specify the imperative military advantage intended to be gained by an attack. ${ }^{79}$ The principle of military necessity is expressly recognized within the codified body of the laws of armed conflict. ${ }^{80}$

Military necessity expresses the idea that for an attack to be lawful, belligerents must be able to show the connection between the attack and the suppression of the enemy's military capability. De Mulinen points out that military necessity pertains to those measures: '(a) not forbidden by the law of war; and (b) required to secure the overpowering of the enemy. ${ }^{, 81}$ This principle imposes the requirement that attackers have identified the prospective target in advance of attack as one that is militarily legitimate. ${ }^{82}$ As a consequence, attacks not directed at a legitimate military target are prohibited. ${ }^{83}$ The important issue is the need to distinguish between civilian persons or objects and military objectives - comprising the elements of 'effective contribution to military action' and 'definite military advantage' specified in Article 52 of Additional Protocol I. ${ }^{84}$

\section{Distinction}

\footnotetext{
77 "Expressions such as 'necessity of military operations,' 'military exigencies, motives and reasons,' 'reasons of war,' and 'security reasons' are synonyms of 'military necessity.' PIETRO VERRI, DICTIONARY OF THE INT'L LAW OF ARMED CONFLICT 75 (Edward Markee \& Susan Mutti trans., Int'l Comm. of the Red Cross 1992).

${ }^{78}$ See McCoubrey, supra note 75.

${ }^{79}$ See VERRI, supra note 77 , at 75.

${ }^{80}$ FREDERIC DE MULINEN, HANDBoOK ON THE LAW OF WAR FOR ARMED FORCES 82-83 (Int'l Comm. of the Red Cross 1987).

${ }^{81}$ See Id. Perhaps subpart (b) of this formulation is the more important as subpart (a), simply invoking that which is not forbidden by the law of war, could apply to any principle of the law of war and says nothing unique about the restrictions imposed by military necessity.

${ }^{82}$ See id.

${ }^{83}$ See id.

${ }^{84}$ DOCUMENTS ON THE LAWS OF WAR, supra note 58, at 448-450.
} 
Distinction is a general principle of the law of armed conflict that requires an attacker to distinguish between civilians and civilian objects on the one hand and military objectives (combatants or objects) on the other, and to use weapons capable of distinction between them. ${ }^{85}$ The principle was initially conventionally articulated within the preamble of the StPetersburg Declaration of $1868,{ }^{86}$ asserting that war is to be conducted only against enemy military forces ${ }^{87}$ and reaffirmed more than a century later by Article 48 of Additional Protocol I. $^{88}$ The principle obliges belligerents to distinguish at all times between non-combatants and combatants, as well as between civilian property and military objectives. ${ }^{89}$

Distinction stresses diligence in "the selection of methods, of weaponry and of targets ... it includes the idea of the immunity of non-combatants and those hors de combat, that is, the sick, wounded, and shipwrecked, but it is not only about that: it can also refer to geographical and other limitations." 90 This description incorporates several concepts, one of the most significant being the distinction between combatants and non-combatants. In general, the law of war prohibits attack of any person deemed a 'non-combatant. ${ }^{91}$ Paradoxically, despite vast improvement in weapons systems accuracy and battle space transparency, complying with the principle may become increasingly difficult. ${ }^{92}$ The problem is that the lines between lawful

\footnotetext{
${ }^{85}$ Additional Protocol 1, supra note 47, art. 48. "In order to ensure respect for and protection of the civilian population and between civilian objects, the Parties to the conflict shall at all times distinguish between the civilian population and combatants and civilian objects and military objectives and accordingly shall direct their operations only against military objectives." Id.

${ }^{86}$ Declaration Renouncing the Use, in Time of War, of Explosive Projectiles Under 400 Grammes Weight, Nov. 29, 1868, 1 AJILs 95.

${ }^{87}$ DOCUMENTS ON THE LAWS OF WAR supra note 58, at 53.. ("[T]hat the only legitimate object which States should endeavor to accomplish during war is to weaken the military forces of the enemy").

${ }^{88} I d$. at 447.

${ }^{89}$ Id. at 447

${ }^{90} \mathrm{Id}$. at 5 ..

91 See Annex to the Convention, Regulations Respecting the Laws and Customs of War on Land, 2 AM. J. INT'L L. 97 (Supp. 1908) (Those military members who should ordinarily fit this category but do not for failure to comply with one of its terms, such as soldiers not wearing a uniform or concealing their weapons, become "unlawful combatants" and risk loss of protections afforded to lawful combatants).

${ }^{92} I d$.
} 
targets and protected objects will blur, due to the growing dependency on civilians and civilian activities during military operations.

Despite these difficulties, it is clear that, as a consequence of the principle, deliberate attacks against civilians and non-combatants are prohibited. ${ }^{93}$ In addition, those engaged in armed conflict must not use weapons that are incapable of distinguishing between combatants and non-combatants. ${ }^{94}$ These requirements illustrate the strong linkages between the scope of international humanitarian law and the development of formal legal principles for the human rights of the individual.

\section{Proportionality}

Even when a belligerent is attacking a legitimate military objective, the extent of military force used and any injury and damage inflicted upon civilians and civilian property should not be disproportionate to any expected military advantage. ${ }^{95}$ This demands an assessment of any potential 'collateral damage' in the case of military action. However, it must be noted that it is often difficult to apply the proportionality principle in practice, given that different people ascribe differing relative 'values' to military advantage vis-à-vis civilian injury and damage. ${ }^{96}$ One only need recall the Advisory Opinion in the Legality of the Threat or Use of Nuclear Weapons, where the International Court of Justice, while noting that the threat or use of a nuclear weapon should comply with the requirements of international law relating to armed conflict, in particular the principles of international humanitarian law, could not say

\footnotetext{
93 Additional Protocol I, supra note 47, art. 48 ("[I]n order to ensure respect for and protection of the civilian population .... the Parties to the conflict shall at all times distinguish between the civilian population and combatants").

${ }^{94} I d$.

${ }^{95}$ See Additional Protocol I, supra note 47, art. 48- art. 52.

${ }^{96}$ See, e.g., Fenrick, supra note 76, at 82-83.
} 
categorically that the threat or use of nuclear weapons would in every circumstance constitute a violation of international law. ${ }^{97}$

\section{THE RELEVANCE OF JUS IN BELLO PRINCIPLES TO OUTER SPACE}

One of the fundamental principles in the Treaty on Principles Governing the Activities of States in the Exploration and Use of Outer Space, including the Moon and Other Celestial Bodies (Outer Space Treaty) ${ }^{98}$ is that activities in the exploration and use of outer space shall be carried out in accordance with international law, including the Charter of the United Nations' (United Nations Charter). ${ }^{99}$ One of the primary reasons for the inclusion of this provision was the concern among many States, even at this relatively early juncture in space activities, that outer space would become a new arena for international conflict. As Bin Cheng aptly put it, 'outer space brought with it a whole new ball game.' ${ }^{100}$ Many of the fundamental principles that formed the basis of the Outer Space Treaty were concluded at a time when the world was in the midst of uncertainty and mistrust, largely as a result of the prevailing geopolitical environment of the Cold War. ${ }^{101}$ Almost as soon as Sputnik I was launched in October 1957, the international community was concerned about the use of outer space for military purposes, as well as the fear that it could perhaps ultimately be used as a theatre of

\footnotetext{
${ }^{97}$ Legality of the Threat or Use of Nuclear Weapons, supra note 4. On this issue the Court was divided equally, with the casting vote of President Bedjaoui deciding the matter: See Statute of the International Court of Justice art. 55, para. 2, June 26.

${ }^{98}$ Treaty on Principles Governing the Activities of States in the Exploration and Use of Outer Space, Including the Moon and Other Celestial Bodies, Jan. 27, 1967, 610 U.N.T.S. 206 [hereinafter Outer Space Treaty].

${ }^{99}$ Id. at art. III. Agreement Governing the Activities of States on the Moon and other Celestial Bodies, art. II, Dec. 18, 1979, 1363 U.N.T.S. 3 [hereinafter Moon Agreement] (extending these sentiments by referring to 'the Declaration on Principles of International Law concerning Friendly Relations and Cooperation among States in accordance with the Charter of the United Nations, adopted by the General Assembly on 24 October 1970). ${ }^{100}$ Bin Cheng, The 1967 Outer Space Treaty: Thirtieth Anniversary XXIII AIR \& SPACE L. 156, 158 (1998)

${ }^{101}$ See id. at 156-58.
} 
war. ${ }^{102}$ In December 1958, the United Nations emphasized the need 'to avoid the extension of present national rivalries into this new field'. ${ }^{103}$

By 1961, the General Assembly had recommended that international law and the United Nations Charter should apply to 'outer space and celestial bodies'. ${ }^{104}$ This was repeated in General Assembly Resolution 1962, which set out a number of important principles that were ultimately embodied in the Outer Space Treaty. ${ }^{105}$ Specific reference to the United Nations Charter was important, given that the maintenance of international peace and security is the underlying principle of the system established under that instrument. ${ }^{106}$ The prohibition on the use of force contained in Article 2(4) of the United Nations Charter represents a crucial element in the regulation of international relations and is equally applicable to the use of outer space. $^{107}$

On the other hand, Article 51 of the United Nations Charter - which confirms the 'inherent right' of self-defence 'if an armed attack occurs' - is also applicable to the legal regulation of outer space. ${ }^{108}$ Under the principles of public international law, this right of self-defence remains subject to express legal limitations - the requirements of necessity and proportionality. ${ }^{109}$ In its Advisory Opinion in the Legality of the Threat or Use of Nuclear Weapons, the International Court of Justice observed: 'The submission of the exercise of the

\footnotetext{
${ }^{102} I d$. at 156 .

${ }^{103}$ G.A. Res. 1348 (XIII), II 3, U. N. Doc. A/4090 (Dec. 13, 1958).

${ }^{104}$ G.A. Res. 1721 (XVI), II 1(a), U.N. Doc. A/5026 (Dec. 20, 1961).

${ }^{105}$ G.A. Res. 1962 (XVIII), II 4, U.N. Doc. A/5656 (Dec. 13, 1963).

106 The first 'Purpose' of the United Nations specified in art. 1 \1 of the Charter begins with the words: "To maintain international peace and security ..." U.N. Charter art. 1, TI1.

${ }^{107}$ Art. 2(4) of the United Nations Charter provides: 'All Members shall refrain in their international relations from the threat or use of force against the territorial integrity or political independence of any state, or in any other manner inconsistent with the Purposes of the United Nations.' U. N. Charter art. 2, ' $\mid 4$.

${ }^{108}$ Art. 51 of the United Nations Charter provides inter alia: 'Nothing in the present Charter shall impair the inherent right of individual or collective self-defence if an armed attack occurs ...' U.N. Charter art. 51.

${ }^{109}$ See People v. McLeod, 1 Hill 377 (1841), (referring to an additional requirement of immediacy). However, this was not mentioned in the recent decision of the International Court of Justice concerning Oil Platforms (Iran v. U.S.), 1996 I.C.J. 803 (Dec. 12).
} 
right of self-defence to the conditions of necessity and proportionality is a rule of customary international law'. ${ }^{110}$ Moreover, even where the right of self-defence is lawfully exercised, the State acting in self-defence remains subject to the jus in bello principles described above. ${ }^{111}$

The sentiments encapsulated in the United Nations Charter were strengthened further by the restrictions imposed in relation to nuclear weapons and weapons of mass destruction by Article IV of the Outer Space Treaty, although, as has been well documented by leading commentators, this provision in and of itself does not represent a complete restriction on the placement of weapons in outer space. ${ }^{112}$ Indeed, there have been, from time to time, proposals put forward to amend Article IV in order to enhance these restrictions, but this has not (yet) eventuated. $^{113}$

The 'peaceful purposes' provision set out in Article IV of the Outer Space Treaty has been the subject of much analytical discussion as to its scope and meaning. While there is general agreement - but not complete unanimity - among space law commentators that this is directed against "non-military" rather than merely "non-aggressive" activities, the reality has, unfortunately, been different. ${ }^{114}$ It is undeniable that, in addition to the many commercial and scientific uses, outer space has and continues to be used for an expanding array of military activities. ${ }^{115}$ Unless concrete steps are taken to arrest this trend - which will require a significant shift in political will, particularly among the major powers of the world - it is likely that space will increasingly be utilized to further the military and strategic aims of

\footnotetext{
${ }^{110}$ Legality of the Threat or Use of Nuclear Weapons, Advisory Opinion, supra note 4, at 245.

${ }^{111}$ See id.

${ }^{112}$ See, e.g., Gyula Gál, 'Threat or Use of Force' - Observations to Article 2 of the U.N. Charter and Article III of the Outer Space Treaty, 17 J. SPACE L. 54, 55-57 (1989).

${ }^{113}$ See, e.g., Vladimir Bogomolov, Conference on Disarmament on Prevention of an Arms Race in Outer Space, 20 J. SPACE L. 35 (1992) (referring to a failed Venezuelan proposal to amend art. IV.).

${ }^{114}$ See Bin Cheng, supra note 100 , at 159.

${ }^{115}$ Id. .
} 
specific countries, particularly as military and space technology continues to evolve and develop.

In this context, if one were to adopt a hard-line pragmatic (and non-legal) view of the current situation, one could suggest that the 'non-military v. non-aggressive' debate is a redundant argument, even though it represents an extremely important issue of interpretation of the strict principles set out in the Outer Space Treaty. Indeed, the focus of much discussion now centres (as it should) on issues involving the "weaponization" of space - witness the numerous United Nations General Assembly Resolutions on that issue. ${ }^{116}$ In one sense, this assumes that the militarization of space is a given, as much as it pains international and space lawyers to admit this. Of course this is highly troubling and flies in the face of the principles of the Outer Space Treaty. ${ }^{117}$ Yet, it would be naive to ignore the realities - what must be done is, instead, to understand what legal principles currently apply to any military activities in space and what more needs to be done to provide, at least from a regulatory perspective, an appropriate framework to protect humankind from what could otherwise be unimaginable scenarios.

As mentioned above, the rules relating to the legal regulation of the use of force $-j u s$ ad bellum - apply to the use of outer space, by virtue of Article III of the Outer Space Treaty, as well as under customary international law. ${ }^{118}$ Much has been written about the application of these principles, which are, of course, extremely important aspects of the use of outer

\footnotetext{
${ }^{116}$ See e.g., G.A. Res. 36/97C, U.N. Doc. A/RES/36/97C (Dec. 9, 1981) and culminating most recently with G.A. Res. 59/65, U.N. Doc. A/Res/59/65 (Dec. 17, 2004) (both being directed towards the 'Prevention of an arms race in outer space.) The political dimensions of this issue in the early 1980 s were indicated by a split, along ideological grounds, on the main thrust of these resolutions: See NANDASIRI JASENTULIYANA, INTERNATIONAL SPACE LAW \& THE UNITED NATIONS 82 (1999).

${ }^{117}$ See Outer Space Treaty, supra note 98, at art. III.

${ }^{118}$ For a discussion on the customary international law status of specific provisions of the space treaties, see Ricky J. Lee \& Steven Freeland, The Crystallisation of General Assembly Space Declarations into Customary International Law, 46 PROC. OF THE COLlOQUIUM ON THE L. OF OUTER SPACE 122, 122-130 (2003).
} 
space. ${ }^{119}$ However, as an integral part of international law, the principles of international humanitarian law, are also highly relevant to the military uses of outer space. There is no specific 'territorial' limitation to the application of the jus in bello principles. The laws and customs of war apply both to the area where the hostilities actually take place, as well as the broader areas that are in some way affected by the hostilities. ${ }^{120}$ If, for example, direct military action takes place in one area, but the effects of that action impact on civilians elsewhere, that represents a relevant consideration in deciding whether such action is consistent with the rules of war - for example with the principle of proportionality. ${ }^{121}$ As a consequence, any military activity that takes place in outer space will be subject to the jus in bello in relation not only to the direct action, but also as to its effects elsewhere, including on Earth.

Having established that these principles can apply to outer space, it is necessary to determine whether this is just an issue of academic curiosity or whether the rules of war are "relevant" to activities in outer space. The answer, unfortunately, appears to be self-evident, as is clearly illustrated by the developments outlined earlier in this article. It seems that outer space may well become a theatre of war in the future.

It was during the Gulf War in 1990 that the value of space assets to the conduct of war was first utilised to a significant degree - indeed, 'Operation Desert Storm' was regarded as 'the first space war'. ${ }^{122}$ It was recognised that the use of space technology would create an

\footnotetext{
${ }^{119}$ See e.g., the papers presented in the session on Legal Implications of Military Uses of Outer Space, 45 PROC. OF THE COLLOQUIUM ON THE L. OF OUTER SPACE 134, 134-277 (2002).

${ }^{120}$ NEED SOURCE

${ }^{121}$ See Fenrick, supra note 76, at 77-83.

${ }^{122}$ Vincent Kiernan, War Tests Satellites' Prowess: Military Space Systems Put to Work during Desert Storm Conflict, Space News, Jan. 21, 1991, 1 (quoting John Pike, Director of globalsecurity.org, a defense policy research organization in Washington, D.C.); See also, John Diedrich, Military Learns from Gulf War Glitches, Updates Space Technology, THE GAZETTE (Colorado Springs), Jan. 27, 2001, available at http://www.globalsecurity.org/org/news/2001/010127-space2.htm.
} 
"integrated battle platform" to aid in the implementation of military strategies. ${ }^{123}$ Following the attacks of 11 September 2001, the United States Administration issued a landmark policy paper in which it emphasised the need for '[i]nnovation within the armed forces [which] will rest on experimentation with new approaches to warfare, strengthening joint operations, exploiting U.S. intelligence advantages, and taking full advantage of science and technology'. ${ }^{124}$ As an integral part of this policy, it was asserted that it was necessary to maintain technological supremacy so as to 'dominate the space dimension of military operations'. ${ }^{125}$ This necessitates having 'the ability to defend the homeland, conduct information operations, ensure U.S. access to distant theaters, and protect critical U.S. infrastructure and assets in outer space. ${ }^{, 126}$

Ballistic missiles play an increasingly important role in any sophisticated national security structure, and the development of defensive systems 'is both a result of and additional factor driving' a global arms race. ${ }^{127}$ In 2001, a commission headed by the former United States Secretary of Defense, Donald Rumsfeld, suggested that an 'attack on elements of U.S. space systems during a crisis or conflict should not be considered an improbable act. ${ }^{, 128}$ The Report went on to (in)famously warn of the possibility of a 'Space Pearl Harbor' - a surprise attack on the space assets of the United States. ${ }^{129}$ The European Union has recently identified outer space as 'a key component for its European Defense and Security Policy'. ${ }^{130}$ Even for smaller

\footnotetext{
${ }^{123}$ See Jackson N Maogoto, Weaponization of Outer Space-From Playground to Battleground: Time to Raise Eyebrows, LLM thesis, 2006 , at 35 (on file with authors),

124 The National Security Strategy of the United States of America, art. IX http://www.whitehouse.gov/nsc/nss.html (last visited Oct. 24, 2007).

${ }^{125}$ See Sa'id Mosteshar, Militarization of Outer Space: Legality and Implications for the Future of Space Law, 47 Proc. OF THE COLlOQUiUm ON THE L. OF OUTER SPACE, 473 (2004).

${ }^{126}$ The National Security Strategy, supra note 124.

${ }^{127}$ Regina Hagen \& Jürgen Scheffran, International Space Law and Space Security, SPACE LAW: CURRENT Problems AND Perspectives for Future Regulation 273 (Martha Benkö \& Kai-Uwe Schrogl eds.,Eleven International 2005).

128 Report of the Commission to Assess United States National Security Space Mgmt. and Org., http://www.defenselink.mil/pubs/spaceintro.pdf 8 (last visited Oct. 5,2007).

${ }_{129} I d$.

${ }^{130}$ Hagen \& Scheffran, supra note 127 , at 281-82.
} 
countries such as Australia, the political exigencies of a post-11 September 2001 world have significantly altered the landscape of national space policy, which now highlights the military and national security concerns associated with the use of outer space. ${ }^{131}$

In addition to the development of a missile defence shield for the advancement of its so-called 'defensive' military utilization of space, the United States has also vigorously pursued its stated goal of space technology superiority. ${ }^{132}$ Space technology played an increasingly important role in the military actions by NATO in Serbia and Kosovo in 1999 and by the 'Coalition of the Willing' forces in Afghanistan in 2001. ${ }^{133}$ During the invasion of Iraq in 2003, the United States used Global Positioning System (GPS) satellite technology to a significant degree to guide and direct so-called 'smart bombs' to their assigned targets. ${ }^{134}$ In late 2006, there were reports emerging of the delivery of a multi-million dollar package of satellite and laser-guided bombs to Israel by the United States, at a time when hostilities in the Middle East were increasing significantly. ${ }^{135}$

In this context, several commentators have opined that space warfare is, in fact, inevitable and cannot be avoided. ${ }^{136}$ If these suggestions turn out to reflect reality, the principles of the laws of war must be applied to any such actions. It is not clear how this should be done in practice or what consequences follow. Especially considering that an important group of space assets used for military purposes are 'dual-use' satellites - which also provide 'civilian'

\footnotetext{
${ }^{131} I d$. at 281. For a discussion of Australia's Space Policy, see generally, Steven Freeland, Difficulties of Implementing National Space Legislation Exemplified by the Australian Approach, in "PROJECT 2001 PLUS" Global AND EUROPEAN CHALlENGES FOR AIR AND SPACE LAW AT THE EDGE OF THE 21ST CENTURY 65, 65-92 (Stephen Hobe, Bernard Schmidt-Tedd, \& Kai-uwe Schrogl eds., 2006) (discussing Australia's Space Policy).

${ }^{132}$ See Hagen \& Scheffran, supra note 127, at 273.

133 NEED SOURCE.

134 NEED SOURCE

135 David S. Cloud \& Helene Cooper, U.S. Speeds Up Bomb Delivery for the Israelis, N.Y. TIMES, July 22, 2006, at A1.

${ }^{136}$ See Iole M De Angelis, Legal and Political Implications of Offensives Actions From and Against the Space Segment, 45 PROC. OF THE COLLOQUIUM ON THE L. OF OUTER SPACE 197, 198 (2002).
} 
communications, remote sensing, and GPS services. ${ }^{137}$ Inevitably, one is drawn to the question of whether, and in what circumstances, such a satellite might now be regarded a legitimate target of war.

Whether space warfare is inevitable and cannot be avoided will depend upon a number of fundamental principles of international law. Clearly, the physical destruction of a satellite would constitute a use of force. Apart from a consideration of the principles in the various space treaties, one would have to determine whether such an action represented a legitimate (at law) use of force, with the only possible justification being Article 51 of the United Nations Charter. ${ }^{138}$ This issue would be determined by a consideration of the necessity and proportionality, as against the armed attack and threat of further attacks, of the act of selfdefence. Even if the action did not violate these jus ad bellum principles, one would then need to consider the jus in bello principles raised earlier.

Let us assume, for example, that a combatant takes the view that a dual-use satellite, for example, a communications satellite, represents a legitimate military objective in accordance with the principles outlined above. Even if this were a correct assessment, the principle of proportionality would continue to apply, so that injury and damage to civilians and civilian property should not be disproportionate to any expected military advantage. Moreover, one could argue that implicit in the principle of distinction is the obligation on the parties to a conflict to take 'all feasible precautions' to protect civilians from the effects of an attack. ${ }^{139}$

\footnotetext{
137 See id. at 201.

${ }^{138}$ U. N. Charter art. 51.

139 HECKAERTS ET. AL., supra note 41, at 70. There would also be adverse environmental consequences (including significant space debris) that may result from the destruction of a satellite. There are, of course, international environmental law principles that would also be applicable in these circumstances.
} 
One can certainly envision that the deliberate destruction of such a target, even if it does not result in any immediate civilian casualties, would have a devastating impact on a community, country or even a region of the world. Millions of lives and livelihoods could potentially be affected, economies destroyed and essential services incapacitated. Obviously, some of the consequences of such an attack may be difficult to foresee, but such action would, one could argue, be regarded at least as reckless. However, there are uncertainties as to whether a 'recklessness' test is applicable in the determination of the proportionality principle. ${ }^{140}$ Given the unique nature of outer space, the principles under the jus in bello, developed as they were largely to regulate terrestrial warfare and armed conflict, are probably neither sufficiently specific nor entirely appropriate to military action in outer space. Even though every effort should be made to define the existing principles as clearly as possible, the looseness of some of the fundamental concepts, as well as the resistance they face from certain States, ${ }^{141}$ means that more specific rules are required if they are to provide a comprehensive framework to protect outer space from becoming another theatre of warfare.

\section{THE INTERSECTION OF LAWS OF WAR WITH SPACE WEAPONRY}

\section{Electromagnetic and Radiation Weapons}

The quintessential electromagnetic and radiation weapon is the nuclear bomb. Electromagnetic and radiation weapons have the capacity to impair electronic circuitry by the

\footnotetext{
${ }^{140}$ For a discussion of the difficulties of applying the proportionality principle in the case of the "high altitude bombing' during the NATO military action in Serbia and Kosovo in 1999, see Steven Freeland, The Bombing of Kosovo and the Milosevic Trial: Reflections on Some Legal Issues, AUST I.L.J. 150, 165-68 (2002).

${ }^{141}$ See Additional Protocol I, supra note 47 (indicating that a number of states have entered a reservation to art. 57(2)(a)(iii) of the Protocol, which prohibits the launching of an attack where the incidental loss, injury or damage to civilians and/or civilian objects would be 'excessive in relation to the concrete and direct military advantage anticipated'). See also ANTONIO CASSESE, InTERnATIONAL LAW 417-20 (Oxford 2nd ed. 2005) (discussing proportionality).
} 
creation and/or emission of electromagnetic pulse (EMP) or radiation. ${ }^{142}$ A nuclear explosion creates both. ${ }^{143}$ A nuclear explosion in outer space can effectively neutralize satellites, which have not been protected through the hardening of its circuitry against EMP or radiations. ${ }^{144}$ EMP are lethal to unprotected circuitry within a very large area, harming satellites several hundred miles from the blast. Beta particles and gamma rays from nuclear explosions may also reduce the functions of space assets as they affect both radio waves and radar waves, important to the functions of satellites. ${ }^{145}$ 'Poorly protected satellites and solar power systems in orbit are particularly vulnerable, because risk radii extend hundreds (sometimes thousands) of miles farther in space than in absorbent air. ${ }^{146}$ This can result in high frequency blackouts over broad areas, followed by periods of impaired radio and radar performance. ${ }^{147}$ The disruptive capabilities of a nuclear blast in space hold distinct military advantages. ${ }^{148}$

Recognizing the utility of nuclear detonations, the first anti-satellite (ASAT) weapon system made operational by the United States involved a nuclear detonation in space. ${ }^{149}$ An EMP is created when 'a cascade of gamma rays from any nuclear explosion in space collides with the upper atmosphere. ${ }^{150}$ Similar to a lightning strike, the EMP lasts only for a millionth of a second but holds potential for devastation of sensitive circuitry. ${ }^{151}$ Unshielded electronics

\footnotetext{
142 John M. COllins, MiLitary SPACE ForCes: The NeXT 50 YeArs 29 (1989).

${ }^{143}$ See id. at 28-30.

144 See, Curtis Peebles, High Frontier: The U.S. Air Force and the Military Space Program 62-65 (1997) (discussing U.S. development of an ASAT system called Program 437 which used a nuclear warhead launched atop a Thor missile with a 1 megaton yield and a kill radius of 5 miles.

${ }^{145}$ Collins, supra note 142 , at 29.

${ }^{146}$ See id. at 31.

${ }^{147} \mathrm{Id}$. at 29-31. (noting that during a detonation at 48 miles $(77 \mathrm{~km})$ altitude on Aug. 1, 1958 over Johnson Island, the United States observed the degradation of high frequency radio traffic throughout a region several thousand miles in diameter for a period of approximately six hours).

${ }^{148}$ Indeed, the Soviet Union used an array of 64 nuclear tipped anti-ballistic missiles around Moscow as a smallarea missile defense system. Code-named 'Galosh,' the system undoubtedly could be converted into an ASAT system. PAul B. Stares, SpaCe AND NATIONAL SECURITY 96 (Brookings Institute 1987).

${ }^{149}$ Though the previous SAINT ('satellite interceptor') system had been developed, it was never fielded. The latter system, known simply as Program 437, utilized a nuclear warhead launched atop a Thor IRBM from Johnson Island in the South Pacific. With a yield of 1 megaton, the warhead had a kill radius of 5 miles. The United States declared the system fully operational on June 10,1964, and it remained in service or available for speedy redeployment until it was terminated on Apr. 1, 1975. See PEEBLES, supra note 144, at 62-65.

${ }^{150}$ Collins, supra note 142 , at 29.

${ }^{151}$ Id. at 29-31
} 
within several hundred miles of the epicenter may be disabled as every unshielded element in its path acts as a conductor. ${ }^{152}$

However, it should be noted that the Treaty Banning Nuclear Weapons in the Atmosphere, In Outer Space and Under Water (Limited Test Ban Treaty) adopted in 1963 forbids nuclear weapon test explosions, or any other nuclear explosions ... '(a) in the atmosphere; beyond its limits, including outer space; or underwater, including territorial waters or high seas; or (b) in any other environment if such explosion causes radioactive debris to be present outside the territorial limits of the State under whose jurisdiction or control such explosion is conducted'. ${ }^{153}$ The military significance of this treaty is essentially its effect as an arms control agreement, as well as an environmental agreement aimed at the prevention of global nuclear contamination.

Although creation of an electromagnetic pulse in space by means of a nuclear detonation may present strategic military advantages, particularly in an anti-satellite role, such activity is forbidden by the treaty. ${ }^{154}$ Significantly, Article IV of the Outer Space Treaty relating to the legal permissibility of satellite interceptors or anti-satellite (ASATs) satellites does not prohibit the transiting, or even the orbiting, of conventional weaponry in space, including ASATs. ${ }^{155}$ The prohibition on orbiting of weapons of mass destruction, including nuclear

${ }^{152} I d$.

${ }^{153}$ Treaty Banning Nuclear Weapon Tests in the Atmosphere, in Outer Space and Underwater, art.I, Aug. 5, 1963, 14 U.S.T. 1313. Interestingly, the drafters sidestepped the vexed issue of where space begins by simply forbidding detonations within the atmosphere and "beyond its limits, including outer space." Id.

${ }^{154}$ Because electromagnetic pulses are not dissipated in space, a single two-megaton bomb exploded at $50 \mathrm{~km}$ or higher above the earth could affect the circuits of nearly all satellites up to the geostationary orbit. GLENN H. Reynolds \& Robert P. Merges, OUter Space: Problems of LAW and Policy 59 ( Westview Press 2d ed., 1997). While military satellites are shielded against such threats, commercial satellites usually are not. Of course, the treaty does not prohibit all explosions in space, only those generated by a nuclear blasts.

${ }^{155}$ Outer Space Treaty, supra note 98, at art. IV. 
weapons, ${ }^{156}$ strongly suggests the distinction between those weapons, and conventional weapons of lesser destructive power, including those directed at satellites.

It is the matter of non-nuclear detonations - which appear not to be specifically prohibited that raises questions regarding the issue of electromagnetic and radiation weapons. ${ }^{157}$ In 1995 , a study for the United States Air Force analyzing the future of air and space power stated in relation to non-nuclear electromagnetic weapons: '[t]he technology of high RF [radio frequency] power and large antennas is about to greatly expand. ${ }^{158}$ The report concluded that when combined, these innovations will allow for the projection of extremely high power densities, including electromagnetic radiation, over extremely long distances to land, air, and space-based targets. ${ }^{159}$ As an example, the report suggests that such a weapon in the geosynchronous orbit could create a six mile footprint on a battlefield which would "blank out" all radar receivers and would damage all unprotected communication sets within that area. ${ }^{160}$ The tremendous power envisioned would also allow injection of signals into even heavily shielded communications networks, allowing for information warfare to be waged at will. $^{161}$

\footnotetext{
${ }^{156}$ Because the Outer Space Treaty does not define "nuclear weapon" its prohibition has stimulated debate over newer technologies such as the X-ray laser which is powered by a nuclear explosion. Whether a nuclear-powered laser is a nuclear weapon will indicate whether it is lawful for it to orbit the earth or not. P. Jankowitsch, Legal Aspects of Military Space Activities, SPACE LAW: DEVELOPMENT AND SCOPE, 147 (Nandasiri Jasentuliyana ed., Praeger Publishers 1992). Given its destructive power, the military significance of such a laser will be tremendous. For example, the intense $\mathrm{X}$-rays emitted as a result of the initial nuclear blast lead some to speculate that one X-ray laser no larger than a packing crate would be able to destroy the entire Russian ICBM arsenal if they were launched at one time in a massive attack. L.B. TAYLOR, JR., SPACE: BATTLEGROUND OF THE FUTURE 36 (Franklin Watts 1988) (1983). In addition to the possibility that such weapons may be nuclear weapons under the Outer Space Treaty, their immense destructive capability may otherwise render them weapons of mass destruction.

${ }^{157}$ Outer Space Treaty, supra note 98, at art. IV.

${ }^{158}$ Ivan Bekey, Force Projection from Space in NEw WORLD VISTAS: AIR AND SPACE POWER FOR THE 21ST CENTURY (SpaCe APPLICATIONS Volume) 83, 84 (USAF Scientific Advisory Board 1996).

${ }^{159} I d$.

${ }^{160} I d$. at 85 .

${ }^{161} I d$. With respect to information warfare, the report gives a number of examples: network viruses, disinformation, memory erasures, and false signals.
} 


\section{Kinetic Energy and Hypervelocity Weapons}

Space weapons characterized by an explosion in proximity to their target are perhaps the most self-evident form of space weaponry. This type of weapon simply steers close to its target and blows it up by detonation in the target's vicinity. ${ }^{162}$ The explosive kill vehicle is rocket launched to coincide with the same orbital plane as the target satellite. ${ }^{163}$ On the back of this technology, and calling into play the LOAC, Article 35 of Additional Protocol I outlines fundamental rules applicable to the methods and means of warfare. ${ }^{164}$ In paragraph 3 , the Article provides: '[I]t is prohibited to employ methods or means of warfare which are intended or may be expected to cause widespread, long-term and severe damage to the natural environment. ${ }^{165}$

The term 'long-term' has been interpreted to mean decades. ${ }^{166}$ In this sense ASAT weapons, which cause such damage, would be prohibited. Considering the effect of space debris that would result from the hard kill of a satellite, such a weapon could arguably be considered to be in violation of this prohibition. However, an ASAT weapon, which would create an EMP without a nuclear explosion, could conceivably not be perceived as a nuclear weapon and fall within the ambit of Article 35(3) Additional Protocol I. ${ }^{167}$ Nevertheless, EMP emissions

\footnotetext{
162 See Stockholm International Peace Research Institute, Space Weapons and International Security-An Overview, SPACE WEAPONS AND INT'L SECURITY 19 (Bhupendra Jasani ed., Oxford University Press 1987). The best example is the Soviet ASAT system, first tested in the late 1960s and deployed in the 1970s. Some conceive this ASAT as a kinetic energy weapon. "The Soviet ASAT system could be categorized as a rocket-propelled KEW [kinetic energy weapon]." However, as its title suggests, a kinetic energy weapon derives its value as a weapon not from an explosive capacity, if any, but its kinetic energy. The design of the Soviet System relies heavily on its explosive charge; the ASAT need not even physically impact its target vehicle.

163 NEED SOURCE

164 Additional Protocol I, supra note 47, at art. 35(2) (representing customary international law); CLAUDE Pilloud et al., Commentary on the Additional Protocols of 8 June 1977 to the GenEVA Conventions OF 12 AUGUST 1949, 416 II 1453 (Yves Sandoz et al. eds., Martinus Nijhoff Publishers 1987).

165 Additional Protocol I, supra note 47, at art. 35 II 1453( C).

${ }^{166}$ PILLOUD, supra note 164 at 416 II 1452.

${ }^{167}$ NEED SOURCE.
} 
might escape from the time requirement of the norm. ${ }^{168}$ The problem with EMP weapons lies with another issue, namely that of distinction. ${ }^{169}$

An ASAT weapon must not have indiscriminate effects. ${ }^{170}$ An attack is considered indiscriminate if either it is not directed at a specific military objective, ${ }^{171}$ or the method or means cannot be directed at a specific military objective. ${ }^{172}$ This may be problematical for an EMP weapon, as is the case if the effects of the means and methods utilized in warfare cannot be limited as required by the Protocol. Thus an EMP weapon would have to be directed at the target satellite in an efficient manner. It is this last condition of an indiscriminate attack, which is also most problematical in the case of a hard kill of a satellite, which causes space debris. The targeting of telecommunication satellites within the LEO orbit once again becomes problematical, since this orbit is shared by many nations.

\section{Directed Energy Weapons (DEW)}

Directed Energy Weapons 'include laser, and radio frequency' weapons. ${ }^{173}$ A laser weapon produces an intense beam. ${ }^{174}$ Laser weapons can be used to either physically harm the satellite or simply to 'blind' a satellite's sensors. ${ }^{175}$ The study of laser weapons, including those capable of disabling satellites, began in the early $1960 \mathrm{~s}^{176}$ and received increased attention as part of the Reagan Administration's Strategic Defense Initiative. ${ }^{177}$ Since then, significant

\footnotetext{
${ }^{168}$ See Collins, supra note 142 , at $28-31$

${ }^{169}$ See ColLINS, supra note 142, at 29 -31. See also Additional Protocol I, supra note 47, at art. 35(3).

${ }^{170}$ Additional Protocol I, supra note 47, at art. 51(4).

171 Additional Protocol I, supra note 47, at art. 51(4)(a).

${ }^{172} I d$. at art. 51(4)(b).

173 Paul B. Stares, The Militarization Of Space: U. S. Policy, 1945-1984 111 (Cornell University Press 1985).

${ }^{174}$ See TAYLOR, supra note 156 , at 22.

175 See id. at 23.

176 STARES, supra note 148 , at 111 ..

${ }^{177}$ See id. at 225.
} 
technical problems have steadily been resolved and lasers stand to radically change warfare. ${ }^{178}$ It is of note that a prototype Alpha laser was successfully tested in 1991 under conditions simulating the space environment. ${ }^{179}$

\section{Information Warfare}

Developed in the 1970s the GPS relies on twenty-four operational satellites in medium-earth orbits in six orbital planes. ${ }^{180}$ Its key function is providing details on direction-where one is located and where one is going. ${ }^{181}$ Significantly, in an age of 'smart' weapons, it is also integral in guiding munitions launched from air, sea, and land-based weapons to their targets, ${ }^{182}$ by providing three-dimensional position and velocity data. ${ }^{183}$ This capability is significant to the execution of military activity and in extension to the laws of war. The system has proved itself highly useful in the last couple of decades ${ }^{184}$ and will be indispensable to

\footnotetext{
${ }^{178}$ During the height of research on the Strategic Defense Initiative many scientists openly questioned that a missile defense project involving space-based lasers could ever work. The Union of Concerned Scientists declared that an effective defense of the U.S. against a Soviet missile defense was unattainable. A report from the Congressional Office of Technology Assessment claimed the likelihood that such a system could protect the U.S. from Soviet missile attack 'so remote that it should not serve as the basis for public expectations or national policy.' TAYLOR, supra note 156, at 24 (Franklin Watts 1988) (quoting Edward Edelson, Space Weapons: The Science Behind the Big Debate, POPUlar SCIENCE (July 1994)). Partly because of the tremendous technical difficulties, the program began to refocus on earth-based lasers.

179 Federation of American Scientists, Space Based Laser ,http://www.fas.org.library.newcastle.edu.au:80/spp/starwars/program/sbl.htm.

${ }_{180}$ See generally Robert A. Ramey, Armed Conflict on the Final Frontier: The Law of War In Space, 48 A.F.L. REV. 1, 17 (2000). See also Maj. LeWonnie Belcher, U.S. Discontinues Selective Availability of GPS to Public, GIS LOUNGE, May 2, 2000, http://gislounge.com/features/us-discontinues-selective-availability-of-gps-topublic/.

${ }^{181}$ Belcher, supra note 180

${ }^{182} I d$.

${ }^{183}$ NEED SOURCE

${ }^{184}$ In response to alleged human rights violations in Kosovo, the North Atlantic Treaty organization (NATO) conducted a bombing campaign directed against the former Republic of Yugoslavia from 24 March - 9 June 1999. This campaign was known as 'Operation Allied Force'. For a discussion of the background to this operation, see Freeland, supra note 49. During the conduct of the campaign, the NATO forces made heavy use of GPS for navigation and precision-guided targeting. Craig Covault, Recon, GPS Operations Critical to NATO Strikes, 150 AVIATION WEEK \& SPACE TECH. 17, 35 (Apr. 26, 1999). However, heavy military reliance on GPS is a double-edged sword because the system is still 'extremely vulnerable to jamming.' Interference by electronic jamming, or even destruction of part of the system by anti-satellite weaponry, might cripple a military force having abandoned its skills in other forms of navigation. DAVID SHUKMAN, TOMORROW's WAR THE THREAT OF HIGH-TECHNOLOGY WEAPONS 164-165 (Harcourt Brace \& Company 1996).
} 
involvement in for future conflicts. ${ }^{185}$ During the first Gulf War, coalition forces were supported by 'the most sophisticated information network ever designed ... dwarfing anything generated in previous wars', with 'approximately 700,000 telephone calls and 152,000 messages per day passed along satellite, microwave, and landlines' ${ }^{186}$ Of particular significance was the role of United States NAVSTAR GPS satellites, which enabled huge numbers of vehicles to "navigate surely across the featureless Iraqi desert in the middle of sandstorm, regularly surprising Iraqi forces ${ }^{187}$ GPS was also used to guide United States Air Force air-launched cruise missiles, hundreds of miles away from their targets, and to guide Navy land-attack missiles. ${ }^{188}$

As the technological information revolution that has characterized late twentieth and early twenty-first century life finds increasing military applications, military strategists are recognizing in new ways the age-old importance of information as a component of warfare. ${ }^{189}$ One commentator has stated that “... information warfare merits attention given its natural connection with space telecommunications systems. Because of heavy U.S. reliance on technology for its military effectiveness, potential threats to the information infrastructure will significantly affect combat readiness.",190

\footnotetext{
${ }^{185}$ NEED SOURCE

${ }^{186}$ John H. Petersen, Info Wars, U.S. NAVAL InST. ReV., May 1993, at 86 (May 1993).

${ }^{187}$ Richard A. Morgan, Military Use of Commercial Communication Satellites: A New Look at the Outer Space Treaty and 'Peaceful Purposes', 60 J. AIR L. \& CoM. 237, 267 (1994).

${ }^{188} I d$., at 268.

${ }^{189}$ General Fogleman, former Air Force Chief of Staff, asserted that "[d]ominating the information spectrum is as critical to conflict now as occupying the land or controlling the air has been in the past." United States Air Force, Air Force Doctrine Document 2-5, Information Operations 1 (Aug. 5, 1998).

${ }^{190}$ Ramey, supra note 180, at 134. See generally Timothy L. Thomas, The Mind Has No Firewall, ForEIGN Military StUdies OfFice Publications, http://leav-www.army.mil/fmso/documents/firewall.htm (last visited Oct. 19, 2007); General Fogleman, former Air Force Chief of Staff, asserted that "[d]ominating the information spectrum is as critical to conflict now as occupying the land or controlling the air has been in the past." United States Air Force, supra note 189.; Joint Chiefs Of Staff Washington DC, Information Warfare. A Strategy for Peace. The Decisive Edge in War, available at http://handle.dtic.mil/100.2/ADA318379 (last visited Oct. 19, 2007).
} 
Considering the tactics of information warfare rely heavily on space assets, it is not drawing a long bow to state that information warfare can be conceived as being a component of space warfare. ${ }^{191}$ Whether classified as an active or passive manipulation of information, a State's information operations in war certainly qualify as a 'means' or 'method' of warfare. ${ }^{192}$ In this respect, information warfare is subject to regulation under the jus in bello. ${ }^{193}$ To be effective against GPS guided munitions, the jamming of GPS signals must be done over a wide area and thus difficulties arise in respect of the principle of distinction. Furthermore, the use of GPS jamming equipment may breach other LOAC principles. ${ }^{194}$

\section{Astronauts from 'Envoys' to 'Combatants'?}

One of the other international treaties directed specifically towards activities in outer space, the Agreement on the Rescue of Astronauts, the Return of Astronauts and the Return of Objects Launched into Outer Space (Rescue and Return Agreement), ${ }^{195}$ sought to clarify the duties of States in relation to astronauts and objects launched into space. ${ }^{196}$ It has been asserted that:

\footnotetext{
${ }^{191}$ Of course, information warfare and the multi-faceted operations it entails is not limited to the space environment. However, with the increasing reliance on space for telecommunications applications, the means of transmitting, intercepting, and corrupting information will entail use of satellite systems.

${ }_{192}$ NEED SOURCE

${ }^{193}$ See generally, United States Air Force, supra note 189.

${ }^{194}$ NEED SOURCE

${ }^{195}$ Agreement on the Rescue of Astronauts, the Return of Astronauts, and the Return of Objects Launched into Outer Space, Apr. 22, 1968, 19 U.S.T.7570, 9574 U.N.T.S. 120 [hereinafter Rescue and Return Agreement] (entered into force Dec. 3, 1968). Although widely used, the shorthand 'astronaut agreement' is unfortunate because it masks the treaty's application to return of objects as well as astronauts. A better shorthand reference would be the 'rescue and return agreement.' CARL Q. CHRISTOL, THE MODERN INTERNATIONAL LAW OF OUTER SPACE 152 (1982).

${ }^{196}$ Though neither term is adequately defined in the international conventional law relating to outer space, it seems best to think of a space object as something distinct from astronauts. However, when international law finally settles on a definition of space object, it may include astronauts. See CHRISTOL, supra note 195, at 153 . The Liability Convention does define space object as including the 'component parts of a space object as well as its launch vehicle and parts thereof.' Convention on International Liability for Damage Caused by Space Objects art. 1(d), Mar. 29, 1972, 24 U.S.T 2389, 961 U.N.T.S. 187. However, in using the very term to be defined within the definition itself, the definition is circular and thus of little assistance.
}

Comment [JMC1]: 1) Pin cite in Christol is wrong 2) Quoted material in parenthetical is missing a source 
Though it appears that space warfare in the foreseeable future will rely primarily on unmanned space activities, the [Rescue and Return] Agreement's provisions on objects as well as those on astronauts will be relevant as a limitation on means and methods of space warfare. The Agreement is essentially an expansion of Article $\mathrm{V}$ of the Outer Space Treaty, which requires States Parties to regard astronauts as "envoys of mankind" entitled to "all possible assistance." 197

Regarding astronauts, the Rescue and Return Agreement requires a State Party to make two notifications. It must either notify the launching authority or make a public announcement, and notify the United Nations Secretary General, ${ }^{198}$ under three conditions: when it receives information or discovers that the personnel of a spacecraft have (1) suffered accident; (2) experienced conditions of distress; or (3) made an emergency or intended landing on territory under its jurisdiction, on the high seas, or on any other place not under any State's jurisdiction. ${ }^{199}$ Further, the Rescue and Return Agreement requires the provision of "rescue" and "all necessary assistance" by States Parties in cases where astronauts land in their territory by reason of "accident, distress, emergency or unintended landing." 200 This assistance is equally mandatory for landings on the high seas or other places not under the jurisdiction of any States, but only for those Contracting States "in a position to do so . . . if necessary. ${ }^{, 201}$

\footnotetext{
${ }^{197}$ Ramey, supra note 180 , at 86 .

${ }^{198}$ Rescue and Return Agreement, supra note 195, at art. 1. Though the treaty does not specify whether the notifications to the launching authority and the United Nations Secretary-General are conjunctive or disjunctive, the language of art. 2 requiring similar notifications is conjunctive. Id. at art. 2.

${ }^{199}$ Rescue and Return Agreement, supra note 195, at art. 2 .

${ }^{200} I d$. This provision further specifies that if assistance by the launching authority would "effect a prompt rescue or would contribute substantially to the effectiveness of search and rescue operations" it shall cooperate with the State Party in whose territory the astronaut has landed. Id. This raises two observations. First, if the conditions for cooperation are satisfied, the launching authority must assist. Secondly, because art. 6 defines a launch authority, in part, as "the State responsible for launching," it could constitute a State other than the astronaut's home state. Id. at art. 6. For example, when the United States launches Canadian, French, or Spanish astronauts on its Space Shuttle, if the occupants were to land in the territory of another contracting party by reason of "accident, distress, emergency, or unintended landing" the United States as "launching authority" could be required under art. 2 to assist in any recovery efforts. Id. at art. 2, 6. Such efforts would then be "subject to the direction and control of the Contracting Party, which shall act in close and continuing consultation with the launching authority." Id. at art. 2. With respect to the treaty, its provisions, including the duty to rescue and assist, formally apply only to States Parties. However, by analogy with Maritime Law, it seems likely that this duty to assist astronauts in distress is rooted in customary international law. The duty to assist mariners on the sea has long been established both by treaty (for example, the 1910 Brussels Treaty) and custom, and likely applies equally to astronauts.

${ }^{201}$ Id. at art. 3 .
} 
The Outer Space Treaty designates astronauts as envoys of mankind and, at the same time, presupposes that States will abide by their obligations to limit national activity in outer space to peaceful purposes. ${ }^{202}$ A necessary precondition for any astronaut claiming combatant status will be some violation of the "peaceful purposes"203 injunction. That being the case, it is implausible to assert that any astronaut qualifying as a combatant, whether acting in an aggressive, non-peaceful role, or a defensive, peaceful role, can be accorded the diplomatic status due an envoy. This conclusion is further supported by the fact that those accorded diplomatic immunity may not engage in armed hostilities. ${ }^{204}$ From this, two commentators have pointed out that '[a] military astronaut [who] participates in hostile acts does not exercise diplomatic functions." ${ }^{205}$ It would simply be incongruous for one person to simultaneously constitute a combatant and an "envoy of mankind." 206 The practical interpretation of the Outer Space Treaty then becomes this: States Parties 'shall regard astronauts as envoys of mankind' only when engaged in 'peaceful' activities, as the Outer Space Treaty assumes them to. ${ }^{207}$ As has been stated by Major Ramey:

The provisions of the Rescue and Return Agreement precipitate the question: "must combatant astronauts be returned in time of war?"

The answer is plainly "no" for reasons similar to those justifying the conclusion that astronauts engaged in armed conflict will not be accorded diplomatic

\footnotetext{
202 Outer Space Treaty, supra note 98, at art. IV.

${ }^{203}$ Ramey, supra note 180 , at 153.

${ }^{204}$ It is for this reason that diplomats stationed in foreign countries are accorded such wide protections under international law. Not only are their personal and professional premises, archives and documents and persons deemed "inviolable," but they are free from the criminal jurisdiction of the receiving State, unless the State of nationality agrees to waive immunity. Vienna Convention on Diplomatic Relations art. 24, Apr. 18, 1961, T.I.A.S. No. 7502, 7310 U.N.T.S. 108.

${ }^{205}$ M. Bourbonniere \& L. Haeck, Jus in Bello Spatialis, 1999 Proc. OF THE SPACE STUDIES INSTITUTE 8 (1999) (conference on space manufacturing). Once a diplomat takes up arms, he arguably loses his diplomatic protections: See John S. Beaumont, Self-Defense as a Justification for Disregarding Diplomatic Immunity, XXIX CAN. YEARBOOK INT'L L. 391, 391 (1991).

206 The Outer Space Treaty itself hints at this by requiring that States Parties regard astronauts as envoys of mankind. This raises the subtle distinction between an astronaut actually being an envoy, and simply being regarded as one. Union of Soviet Socialist Republics, United Kingdom of Great Britain \& Northern Irelend, United States of America, Afghanistan, Argentia, etc., art. V, jan. 27, 1967208.

${ }^{207}$ Outer Space Treaty, supra note 98 , at art. V.
} 
immunity. . . . The opposing belligerent will owe no greater duty to return the prisoner of war from space than it would the prisoner of war from the land, sea, or air. $^{208}$

\section{CONCLUSION}

Consideration of technologies useful for space combat will proceed under the principle that State action is permitted in the absence of clear legal prohibition. ${ }^{209}$ Though regularly denounced by a large segment of the international community as destabilizing for the use and exploration of outer space, ${ }^{210}$ in principle none of the potential means and methods of space warfare, with the exception of nuclear weapons and weapons of mass destruction, violate international law. ${ }^{211}$ of course, the use to which these weapons are put might render them

\footnotetext{
${ }^{208}$ Ramey, supra note 180 , at 153.

${ }^{209}$ See Freeland, supra note 140.

${ }^{210}$ Indeed, the Soviet Union went so far as to present a "Draft Treaty on the Prohibition of the Stationing of Weapons of Any Kind in Outer Space" to the 36th Session of the United .Nations General Assembly on 20 August 1981. In the relevant part, the draft treaty would have required States Parties “... not to place in orbit around the earth objects carrying weapons of any kind, install such weapons on celestial bodies, or station such weapons in outer space in any other manner, including on reusable manned space vehicles of an existing type or of other types which States Parties may develop in the future." Draft Treaty on the Prohibition of the Stationing of Weapons of Any Kind in Outer Space, U.N. GAOR, 36th Sess., Annex, U.N. Doc. A/36/192 (1981) (presented to the U.N. Secretary-General by the U.S.S.R. Minister for Foreign Affairs on Aug. 10, 1981). It would have equally required States Parties 'not to destroy, damage, disturb the normal functioning or change the flight trajectory of space objects of other States Parties, if such objects were placed in orbit in strict accordance with art. 1, para. 1, of this treaty.' ( Id. at art. 3). While the draft treaty would not have prohibited land-based ASATs, it would have significantly expanded the scope of the partial de-weaponization provisions of Article IV of the Outer Space Treaty. See generally COLIN S. GRAY, AMERICAN MILITARY SPACE POLICY: INFORMATION SYSTEMS, WEAPON SYSTEMS \& ARMS CONTROL 115 (1982). The United States dismissed the Soviet draft treaty as a 'hypocritical propaganda ploy.' STARES, supra note 173. Following announcement that the U.S.S.R. would unilaterally refrain from deploying ASATs "for the entire period during which other countries, including the U.S.A., will refrain from stationing in outer space antisatellite weapons of any type," the Soviets presented a second draft treaty that would have prohibited the testing and deployment of "any space based weapons intended to hit targets on the Earth, in the atmosphere, or in space." Id. at 231. Over great scientific and congressional pressure, the Reagan administration rejected this proposal, at the same time citing the extreme difficulty, if not 'impossibility,' in verifying an ASAT treaty. Id. at 233.

${ }^{211}$ Following a discussion of the relevant provisions of the Outer Space Treaty and the Moon Agreement, Professor Christol observed in 1988 that "[i]n the years since the 1967 [Outer Space Treaty] and 1979 the [Moon Agreement] science and technology have perfected new generations and families of weapons, including those employing highly focused energy, such as laser weapons, and those based on sub-atomic particles, such as particle beam weapons. Pursuant to the general legal principle that which is not prohibited is permitted, it may be concluded that the more recent exotic weapons do not fall within the constraints of the foregoing treaty provisions." Carl Q. Christol, Outer Space: Battle-Ground of the Future?, in SPACE LAW: PAST, PRESENT, AND FUTURE 59 (Carl Q. Christol ed., 1991). The Russians have objected to the orbiting of particle beam weaponry, claiming that it constitutes a "weapon of mass destruction." TAYLOR, supra note 156, at 34. However, given its likely capacity for great precision, the weapon need not generate "mass" destruction, though it may be lethal for its intended target. Some authors suggest that just about all space weapons constitute weapons of mass
} 
unlawful for a specific objective if, for example, their use rendered them disproportionate (or indiscriminate or inhumane) under the laws of war as judged against the military objective in view. But this is an inherent possibility for any weapon, which, by itself, does not render the weapon unlawful. In the words of Colleen D Sullivan:

\begin{abstract}
Although the role of custom in the development of modern international law has evolved, it is still a valid and important source of modern law. What is different, however, is that in an era of sophisticated satellite communications, the development of customary legal principles has become an accelerated process rather than a gradual evolution. In addition, the growing significance of international governmental organizations with their plenary decision-making process, often by consensus, has created a procedure by which custom can coalesce into customary principle and develop into codified law within a relatively short period of time. ${ }^{212}$
\end{abstract}

So important are space systems to military operations that it is unrealistic to imagine that they will never become military targets. Just as land dominance, sea control, and air superiority have become critical elements of current military strategy, space superiority is emerging as an essential element of battlefield success and future warfare...An increased dependence on space capabilities may lead to increased vulnerabilities. As space systems become lucrative military targets, there will be a critical need to control the ways in which space is utilized in future armed conflicts.

Although the existing jus in bello principles, which also apply to outer space, provide some underlying standards that regulate the utilization of space for the purposes of armed conflict, the unique nature of space requires that the applicable rules be strengthened and particularized towards the environment of space. For example, with the exception of those Treaties that seek

destruction. See M.N. Andem, Implementation of Article IV of the Outer Space Treaty of 1967 During the 21st Century, Proceedings of the Fortieth Colloquium on the LaW of Outer Space 338, 334 (American Institute of Aeronautics and Astronautics 1998).

${ }^{212}$ Colleen D. Sullivan, The Prevention of an Arms Race in Outer Space: An Emerging Principle of International Law (1990) 4 TEMP. INT’L \& COMP. L.J. 211, 229 (1990). 
to ban the use and testing of certain types of weapons, there are many uncertainties that arise when one seeks to apply these principles to a (at this stage hypothetical) space conflict. The consequences of a space war are potentially so enormous that one cannot be sure as to exactly how these rules - for example, the principle of proportionality - will apply.

In doing so, if we are to avoid 'grey areas' in the law, it is necessary to develop specific and clear rules and standards that categorically sanction the weaponisation of space, as well as the engagement in any form of conflict in the region of space and against space assets. The Outer Space Treaty, as well as the other space treaties and General Assembly Resolutions, do not currently provide stringent rules nor incentives to prevent an arms race in outer space, let alone conflict in space. This may, therefore, require additional space law regulation directly applicable to armed conflict involving the use of space technology. As part of these new rules, clear definitions need to be developed for concepts such as 'space weapons', 'peaceful purposes' and 'military uses'. Moreover, the fundamental issue of 'where space begins' should be definitively resolved so as to counter any arguments that outer space is, in fact, an area akin to the territory of a State for the purposes of national security. Even more significantly, in developing these new rules, we need to adhere strictly to the 'collective humanity' principles inherent in both the jus in bello and the international law of outer space in order to avoid the possibility of alternate scenarios too frightening to contemplate. 